Братерська-Дронь М. Т.

\title{
«У РОБОТІВ - СВОЇ КАЗКИ» (РОБОТОТЕХНІЧНА ПРОБЛЕМАТИКА В СОЦІОКУЛЬТУРНОМУ ПРОСТОРІ ХХ - ПОЧАТКУ ХХІ СТ.)
}

\begin{abstract}
Статтю присвячено проблемам робототехніки в сочіокультурному просторі $X X$ $X X I \mathrm{~cm}$.

Ключові слова: робототехнічна проблематика, сочіокультурний простір XX-XXI cm., коеволюиія людини й робота.
\end{abstract}

The article is devoted to the problems of robotics in the socio-cultural space of the XX-early XXI centuries.

Keywords: work-related problems, socio-cultural space of the XX-XXI centuries, coevolution of man and work.

Статья посвящена проблемам робототехники в сочиокультурном пространстве $X X-$ $X X I \mathrm{~cm}$.

Ключевые слова: робототехническая проблематика, сочиокультурное пространство XX-XXI cm., коэволючия человека и робота.

Робототехнічна проблематика $є$ однією 3 найбільш актуальних у сучасному соціокультурному просторі. Механічна людина 3'являлася в культурних традиціях нашої цивілізації неодноразово. Її інваріації знаходимо в упанішадах, Кабалі, міфах Стародавньої Греції.

Зокрема в міфах Криту згадується історія гігантського робота Талоса, або Тала. За однією з версій, Талоса подарував Свропі закоханий у неї Зевс. За іншою легендою, бронзового гіганта викували Гефест із Циклопом і подарували його цареві Криту Міносу, у царстві якого він виконував захисні функції. Коли суворого велетня поранили в «слабке місце» - кісточки, із нього замість крові потекло щось, що нагадувало розплавлений свинець.

Гомера вважають першим фантастом в історії, який офіційно зафіксував створення штучної людини. В «Іліаді» він описав створення богом-ковалем Гефестом механічної красуні із золота. Далі були два міднокопитних бики Еєта (Аєта) - царя Колхіди, які випромінювали полум'я зі своїх ніздрів і яких здолав Ясон. До речі, перші людиноподібні автомати були створені в Стародавній Елладі в храмах. Ковтнувши монетку, вони відмірювали певну міру благовонної олії. А от мідний Молох задовольнявся немовлятами, яких йому приносили в жертву.

Та хоч що було б у стародавніх легендах і переказах, приблизно в 1595 р. Леонардо да Вінчі спроектував (i, вірогідно, навіть побудував) механічного лицаря в броні, який скоріш за все й став першою людиноподібною машиною в історії людства. Як свідчили креслення, усередині робота перебував механізм, який приводив його в дію за допомогою тросів і роликів, створюючи ілюзію присутності в 
ньому реальної людини. Цей робот міг рухати головою, руками й ногами, навіть рухатися під акомпанемент барабанів.

Створення людиноподібної істоти, довершеної фізично та інтелектуально, заповітна мрія людства. Проте серйозно за нею взялися спочатку фантасти, а вже потім науковці.

Початківцем цієї теми в літературі прийнято вважати англійську письменницю Мері Шеллі, а саме їі роман «Франкенштейн, або Сучасний Прометей» (1818). Цікаво, що в самій назві авторка акцентує сюжет повстання творіння проти свого творця (Прометея проти богів). Надалі ідея персоніфікації, свободи вибору штучного створіння стане провідною у філософському осмисленні робототехнічної проблематики.

У цей час сучасність не відставала від літератури. У 1883 р. такий собі Дж. Мур створив першу парову людину силою 0,5 кінських сил. Такий апарат міг пересуватися зі швидкістю 14 кілометрів за годину.

Кінематограф виявляє зацікавленість цією темою буквально 3 перших кроків свого існування. Фільм «Голем» (1914, реж. Г. Гален, П. Вегенер) розповідав історію, записану в Талмуді про празького рабі Лева Бецалеля, який зліпив із глини й оживив людиноподібну істоту для захисту єврейської общини.

Одначе тема штучної людини в iї сучасному робототехнічному трактуванні зробила першій крок у світ із легкої руки К. Чапека, із його п’єси «Р.У.Р.» (1920). Саме чеський письменник уводить в ужиток термін «робот» (в англійському перекладі). Історія, що трапилася в якійсь країні, розповідала про повстання машин, наділених не лише інтелектуальними, фізичними, а й психологічними можливостями. Ці створіння повстали проти людей, і це зрештою закінчилося повним знищенням людства як біологічного виду. Звичайно, це був лише поверхневий шар твору, що давав авторові можливість пильніше вдивитися в сутність людського єства, осмислити його переваги й вади. «Зізнаюсь, - нотував К. Чапек, - що до написання цієї п’сси мене спонукала іiі фабула, особливо ті два акти, де жменька людей очікує смерті з високо піднятою головою; людський героїзм - моя улюблена тема, і він власне і привернув мене до цього сюжету. Хоч що б випливало з готової п’єси, я залишився вірним цій ідеї... для мене йшлося не про роботів, а про людей... Я думав про цінність кохання і праці, натхнення і віри, героїзму і творчості; про роботу духу, про бадьорість і самопожертву, про простоту і набожність, про велику шанолюбність і ніжне співчуття, про переможний дух людства...» [9, с. 436].

Проте письменник оспівував не тільки творчу міць людини, а й тонко підмітив вади людської цивілізації. Недарма один із роботів скаже: «Треба вбивати й володарювати, якщо хочеш бути як людина. Читайте історію! Читайте книжки людей! Треба володарювати й убивати, щоб бути людьми!» [9, с. 173]. Зрештою, світ людей, який повністю обслуговують машини, став ледащим, заплив інтелектуальним жирком i навіть перестав розмножуватися, «оскільки людина стала, суто кажучи, пережитком», отож був знищений істотами, здатними розвиватися. П'єса закінчується тонкою іронією, фантастичним сподіванням: пара еволюційно просунених роботів, наділених людськими властивостями, можливо, зможе дати початок новій цивілізації 
олюднених роботів.

По суті, К. Чапек на початку ХХ ст. визначив головні філософські аспекти сучасної робототехніки. Наразі була необхідною велика проникливість, щоб угледіти ще не означені чітко проблеми.

Однак водночас постає інша тенденція, протагоністи якої прагнуть «примирити» людину і машину, утворюючи таким чином новий бездоганний тандем існування цивілізації.

Іще 1912 р. відомий російський учений, фізик-теоретик М. Умов у праці «Роль людини у світі, що нею пізнається» покладає на машинерію великі сподівання щодо гармонізації навколишнього світу: «Чіткий механізм прагне створити оточення, яке б перебувало з ним у резонансі, а не у перебої. Іншими словами, він гармонізує усе довкілля відповідно до власного відчуття краси, підпорядковує це оточення своїм ідеалам» [8, с. 122]. Учений також припускає, що в майбутньому технічний прогрес довершить машини до такого рівня витонченості, що керування ними дедалі більше наближатиметься до виду мистецтва, наприклад, до виконання музичної п'єси. Надалі також зростатимуть вимоги до людей, які керують машинами, праця котрих усе більше нагадуватиме творчий процес.

«Друг i співець» машин М. Умов був далеко не поодинокий. Ідея «тейлоризованої» людини проникає в мистецтво. З’являється образ нового героя машини - як символу досконалого руху (нової тварини з інстинктами). Цей тип героя був визначений італійськими футуристами в 1914 р. як «механічна людина 3 частинами, що легко замінюються» [5, с. 55].

Один із засновників нової концепції актора в Росії С. Волконський у 1913 р. відверто порівнював людину 3 машиною, яка «приводиться до дії» та «змащується» почуттями, але оскільки вона машина, то підкоряється загальним законам механіки [10, c. 186].

Популярними стають ідеї так званої біомеханіки, спроби перенести принципи роботи механізмів на біологію людини. У мистецтві $20-x$ pp. із надзвичайною швидкістю поширюються ідеї машинізму, захоплення конструктивізмом.

Ця тенденція яскраво виявилася в архітектурі, театрі, кінематографі. Зокрема ідеї конструктивізму сягають високої мистецької виразності у творчості відомих архітекторів Л. Корбюзьє, В. Гропіуса, Б. Таута. У радянському мистецтві данину конструктивізму сплачують відомі режисери кіно й театру С. Ейзенштейн, Л. Кулешов, В. Мейєрхольд, О. Таїров та ін.

Режисер і оператор, один із засновників радянського кіноавангарду Дзига Вертов (Давид Кауфман) 1922 р. писав: «У нас немає підстав у мистецтві руху приділяти головну увагу сьогоднішній людині. Соромно перед машинами за невміння людей тримати себе, проте що поробиш, коли безпомилкові манери електрики хвилюють нас більше, ніж безладна маячня активних і розкладаюча млявість пасивних людей... $M u$ виключаємо тимчасово людину як об 'єкт кінозйомки за ї̈ невміння керувати своїми рухами. Наш илях - від громадянина, який копирсається, крізь поезію машини до досконалої електричної людини. Розкриваючи душу машини, закохуючи робітника у верстат, закохуючи селянина в трактор, машиніста в потяг, ми вносимо творчу радість 
у кожну механічну працю, ми споріднюємо людей з машинами, ми виховуємо нових людей» [2, с. 47].

У світі танцювального мистецтва популярності набувають експерименти радянського режисера й балетмейстера М. Фореггера, який здійснив відому постановку «Танців машин», де акробатика й танці відображали виробничі процеси.

У 20-ті pp. ХХ ст. хвиля ідеалізації й романтизації технічного аспекту буквально захлеснула людство. Є. Зам'ятін в одному з перших радянських романів-антиутопій «Ми», іронізуючи 3 цього приводу, від імені свого героя говорив: «Сьогодні вранці я... побачив верстати: із заплющеними очима, із самозабуттям, кружляли кульки регуляторів; мотилі 3 блиском згиналися праворуч і ліворуч; гордовито колихав плечима балансир; у такт нечутній музиці присаджувалося долото довбального верстата. Я раптом побачив усю красу цього грандіозного машинного балету, забарвленого легким блакитним сонцем» [3, с. 309].

Проте далеко не все мистецтво 20-х рр. було настільки оптимістичним. Зокрема 1926 р. виходить картина Ф. Ланга «Метрополіс». Цей фільм, на наш погляд, заклав філософські засади сучасної робототехнічної проблематики. Картина відкривалася концептуальним титром: «Ми живемо у світі матеріальних досягнень, небувалого розвитку науки. Але що відбувається з нашими серцями й нашим розумом? Чи буде наше майбутнє таким, як у цьому фантастичному місті?»

Й ось ми бачимо індустріальне суспільство, де штучне середовище витіснило реальну природу, - жахаючий своєю безликістю, затхлістю й бездушністю мегаполіс, де немає ані сонця, ані свіжого повітря; однотипні будівлі, між якими приречено рухається натовп робітників; однотипні люди, які скоріше скидаються на роботів, механічно пересуваючи ноги, із низько схиленими головами. Це рядові великого підземного мурашника, які мають працювати, аби не вмерти 3 голоду. У картині Ф. Ланга тейлоризація людини постає радше як антигуманний фактор суспільства. Ця ідея втілюється в символічний візуальний образ робітника, розіп'ятого на величезному циферблаті годинника (Христос індустріальної доби), який неймовірним зусиллям волі контролює життя мегаполісу. I знову спливає міфологічний Молох образ безжалісного й байдужого індустріального міста, - що потребує нових і нових жертв рабської праці.

Та ось ми потрапляємо зовсім до іншого світу - матки-еліти Метрополісу недоторкана природа, буяння рослинності, фонтани, павичі. Тут все сяюче, «плавне» у своїх формах, які надають свіжості повітрю, сповненого щасливого життя. Світ несправедливо поділений на безтурботну купку олігархів із їх сім'ями й нужденну масу рабів, що їх обслуговують. «Дивіться, діти, це ваші брати!» - говорить учителька наляканим дітям із «низинного» світу, які ненароком потрапили до незнаного едему.

У робітничих катакомбах наростає бунт. На замовлення Господаря міста демонічний учений Ротвангер створює робота-жінку, надаючи їй риси якоїсь учительки Марії, у яку закоханий син Господаря. Епізод оживлення робота шляхом перекачування життєвих сил від реальної Марії відтворений блискуче: електричні дуги, колби, численні перехідники й дроти, якими сочиться живильна рідина. 
Поступово машина олюднюється, 3'являються кістки, система кровообігу, обличчя набуває живих, реальних рис. Оживлена механічна істота з жахливим сміхом сходить зі свого п’єдесталу. Та замість того щоб угамувати робітників, робот розпалює бунт, $\mathrm{i}$ починається повстання: люди знищують не тільки ненависні машини, а й усе, що їх оточує, навіть свої жалюгідні помешкання, - суцільний Армагеддон.

Картина Ф. Ланга закінчується оптимістично: народ прозріває, гнобителі миряться із гнобленими, головне зло - диявольське творіння злодія-вченого Ротванга, робот - гине в очищувальному полум'ї.

Науково-технічна революція, що розпочалася після Другої світової війни, а саме в другій половині 1950-х рр., розширила уявні можливості традиційної науки, визначила нові технічні перспективи розвитку сучасної цивілізації.

Звідтоді робототехнічна тема буде безпосередньо пов'язана 3 космічною. Наприкінці 50-х рр. американські інженери Манфред Е. Клайнс та Натан С. Клін працювали над проблемою можливості адаптації людини до умов космосу й інших планет. У процесі дослідження вони дійшли висновку, що оптимальним засобом вирішення цієї проблеми може стати поєднання людини й робота. Спочатку ця ідея викликала різку критику, проте досить швидко в неї з'явилося багато прихильників у науковому світі. Так виник термін «кіборг».

Щоправда, постає питання: чому сучасний робот мав скидатися на людину? Звичайно, відповідь крилася не в наївному припущенні - щоб людина не лякалась або психологічно їй було зручніше сприймати свою подобу. Учені вважають, що людська природа, iї біологічний вигляд найбільш відповідає земному існуванню, особливостям довкілля. Отже, робот, який наслідує біологічні особливості людини, може оптимально пристосовуватися до аналогічних обставин і в разі необхідності надати достовірне уявлення про людину в інших світах космосу.

1967 р. на екрани виходить радянський фільм, який сьогодні мало хто згадує, «Його звали Роберт», поставлений режисером I. Ольшвангером.

Ця кінострічка була створена в жанрі ліричної комедії й стала свого роду відгуком кінематографістів на доволі гостру полеміку, що мала місце в 60-ті рр., між фізиками й ліриками під алегоричною назвою: «Чи потрібна гілка бузку в космосі?»

Робототехнічна тема також поєднувалася з космічною, щоправда, не відігравала в сюжетній лінії принципового значення. Молодий учений Сергій Сергійович із символічним прізвищем Куклін створює робота «модель РБ-235» на ім'я Роберт 3 метою космічної подорожі на Вегу (обидві ролі виконував актор О. Стриженов). Роберт як викапаний схожий на свого деміурга не лише обличчям, але й рисами характеру. Сергій Сергійович наділяє його ними на свій розсуд, він навчає Роберта певним сентенціям: «Душа - здатність організованої матерії відображати матеріальний світ. Краса - бути кращим, ніж насправді, що є однією 3 найбільш закоренілих помилок людства. Жалість, горе, радість - необов'язкові показники». Один із колег Кукліна запитує його: навіщо він створив Роберта за образом і подобою своєю? На що Сергій Сергійович відповідає, що на Везі той зможе зустрітися 3 розумними істотами, які по ньому судитимуть про людей. «А ти не боїшся, - запитує колега, - що по ньому судитимуть не тільки про рівень нашої техніки, а й про нашу 
душу?». - «Ні, не хвилююсь, - відповідає той, - адже душа - лише здатність організованої матерії відображати матеріальний світ».

Для апробації конструкції, самостійності робота, його, так би мовити, випускають «у люди». Потрапивши на вулиці міста, безпосередньо контактуючи 3 людьми, Роберт спочатку поводиться згідно 3 програмою, підпорядкованою формальній логіці: запалює світло в концертному залі, щоб краще бачити, пересуває на свій розсуд стільці, вихоплює з рук диригента його паличку, щоб не розмахував руками й не заважав дивитися виставу, керуючись іронічним наказом, стрибає 3 мосту й т. ін. «Учися думати, а не просто обчислювати», - зауважує йому Куклін. Та 3 часом, аналізуючи реакцію людей на свої вчинки, Роберт усе більше відчуває себе самотнім. Дедалі частіше звучать драматичні нотки. Він тяжіє до подібних собі - до механічної іграшки-жабки, слухняного волі людської руки матерчатого Петрушки, про якого із сумом скаже: «Він такий самий, як я, тільки маленький і примітивний». Роберт намагається в усьому наслідувати людину, але поступово усвідомлює свою недосконалість. У нього розвивається комплекс неповноцінності. «Я хочу знати, як пахне сіно. Я хочу купатися в дощ. Я теж хочу помилятися», - заявляє він своєму творцеві. Можливо, Роберт не може робити всього цього не тільки тому, що він машина, але й тому, що Куклін просто не заклав ці здатності як необов'язкові й навіть зайві. Намагаючись зробити неможливе - проникнути в емоційний світ людини, робот витрачає всю свою енергію й стає безпорадною лялькою, яка безсило повисає на плечі свого творця.

Та, окрім цікавої лінії «олюднення» машини, у картині наявний оригінальний сюжетний хід «роботизації» людини. У результаті з'ясовується, що Сергій Сергійович більше схожий на добре налагоджений механізм, ніж його технічне створіння. «Я десь читала, - каже йому одна з героїнь, - що машина - це рукавичка, одягнена на руку людини. А ви погана людина, жорстока. I ви не маєте права командувати машиною».

Цікаво, що саме машина захищає та відстоює багатство й неповторність емоційного світу людини. Філософський підтекст, означений ще Мері Шеллі, у 60ті pp. XX ст. отримав подальше наповнення.

У фільмі радянських кінематографістів робот хоча й намагався відстоювати свою «особистість», право на певну свободу, усе ж таки був помічником людини, який підкорюється ii наказам. Тут ще діють головні закони-скрижалі робототехніки, сформульовані відомим письменником-фантастом А. Азімовим в оповіданні «Брехун!» (1941). Вони проголошують: 1) робот не повинен завдавати шкоди людській істоті або своєю бездіяльністю допускати, щоб їй шкодили; 2) робот підкоряється наказам, що надходять від людських істот (проте якщо вони не суперечать Першому Закону; 3) робот повинен піклуватися про своє існування (якщо діï такого роду не суперечать Першому та Другому законам). Пізніше А. Азімов доповнив ці положення нульовим законом.

Однак, 60-ті рр. минулого століття позначилися не тільки стрімким розвитком науково-технічної революції, а й усвідомленням iï так званих негативних або супутніх проблем. Пропорційно до того, як зростали надбання й успіхи в галузі науки та 
техніки, накопичувалися проблеми в соціальній i духовній сферах. Сучасна цивілізація все більше нагадувала безпечного суб'єкта, який «пиляв сук, на якому сидів». Людство в прагненні полегшити своє життя (підгрунтям якого по суті були звичайні лінощі) дедалі більш ставило себе в залежність від штучного середовища, яке накопичувалося із геометричною прогресією. Сьогодні навіть страшно уявити, що може статися, наприклад, коли вийде з ладу світова комп'ютерна мережа. Зокрема сучасна робототехніка має набагато більше питань та аспектів, ніж може здатися.

Ну от, скажімо, закони робототехніки А. Азімова. Моделюємо таку ситуацію: пожежа, робот повинен рятувати людей, що опинились у небезпеці: дітей, молодих людей, старих, інвалідів. Кому він має забезпечити безпеку передусім? Дітям? А може, молодим людям, які можуть дати нове потомство й без яких, як у тваринному світі, існування малечі не має сенсу? А може, усе ж таки старим і кволим, про яких у тваринному світі ніхто не піклується?

I щоб розв'язувати ці питання, робот повинен мати хоча б якісь уявлення про суспільну етику i, головне, мати особисту мораль. А відтак робот має бути наділений певною свободою особистого вибору в ухваленні рішень. Ну, і що тут будемо робити зі славнозвісними принципами робототехніки?

На цій хвилі цілком зрозумілого філософського скептицизму з'явилася знакова кінострічка англійського режисера С. Кубрика «2001: Космічна одіссея» (1968), знята за сценарієм відомого письменника-фантаста А. Кларка.

Насамперед картина цікава тим, що створювалася на перетині двох головних тем наукової фантастики - космічної й робототехнічної. Пролог фільму віднесений у доісторичні часи, коли первісна людина, яка перемогла ворога, у радісному пориві кидає вгору кістку, яка на тлі зоряного неба перетворюється на космічний корабель. Так здійснюється одвічна мрія про опанування космічним простором. Автори переносять нас у XXI ст. Під поверхнею Місяця знайдено таємничий чорний моноліт, падіння на нього сонячного проміння сигналізує на Сатурн, що космічна ера на Землі розпочалася.

До Сатурна в повній секретності збирається експедиція. Її мета відома лише трьом ученим, які перебувають в анабіозі, та електронному мозкові, що керує польотом.

Комп'ютер повинен приховувати навіть від капітана мету експедиції, що викликає в нього певні комплекси, відчуття своєї недосконалості. «Він, створений, щоб говорити правду, весь час брехав, і наближувалася мить, коли його колеги дізнаються, що він допомагав ошукувати їх... суперечність, яка повільно, проте впевнено підточувала цільність його електронної психіки... Він почав помилятися... Проте цей конфлікт не мав принципового значення. ЕАЛ подолав би його, - адже більшість людей також якось справляються зі своїми неврозами, - якби не опинився перед обличчям кризи , що поставила під питання саме́ його існування . Його погрожували відключити... Для нього це було рівнозначно смерті... I він почав захищатися усіма доступними йому засобами. Без злоби - проте й без співчуття - він вирішив усунути все, що йому заважає. А потім, підкорюючись програмі, закладеній у ньому на випадок надзвичайних обставин, він доведе завдання експедиції до кінця - 
сам, без усяких перепон» [4, с. 168-170].

Одного за одним комп'ютер знищує членів екіпажу. Одного відправляє у відкритий космос, від'єднує від життєдайних функцій астронавтів, що перебувають в анабіозі. I якщо смерть людей показана безпристрасно, фактично без емоцій, то смерть електронної машини стає найбільш емоційно сильним епізодом фільму.

Капітан корабля, усвідомивши ситуацію, починає по черзі від'єднувати блоки електронної пам'яті. Комп'ютер, як беззахисна людина, благає прощення, умовляє не позбавляти його розуму. Поступово його мова стає плутаною, недоладною, переходить у нерозбірливе белькотіння, немов умирає жива істота.

Після Чапека про роботів писали багато. Утім, можливо, лише кілька книжок стоять окремо: збірка оповідань «Я - робот» А. Азімова, а також «Сума технологій», «Казки роботів» та «Кіберіада» С. Лема. У цих творах головним героєм стає робот. Автори намагаються відтворити можливі моделі ситуацій і конфліктів у системі «людина - машина», дослідити, так би мовити, формулу не тільки суто людського, а й штучного інтелекту.

Окремо треба сказати про твори С. Лема. Свого часу навіть існувала думка, що ніякого Лема не було, а був ЛЕМ (Літературна Електронна Машина), невеликий на зріст чоловік, медик за освітою, який народився у Львові, жив у передмісті Кракова та був лише придатком до цієї машини. Так чи так, але існував справжній Лем, який в історії науково-фантастичної літератури залишився співцем людського й талановитим дослідником штучного. Мабуть, предтечею циклів оповідань «Казки роботів» (1964) та «Кіберіада» (1965) стала «Одинадцята подорож Йона Тихого», у якій розповідалося про Головного Калькулятора космічної ракети, який, не витримавши насміху на свою адресу, повстав проти людей, викинув увесь екіпаж корабля, висадився на невідому планету й заснував там імперію роботів. Похідним матеріалом для нього став сам космічний корабель 3 усією його начинкою. Так виникла «культура» роботів: вони видають свої газети, спілкуються архаїчною мовою людства, відрізняються агресивністю (оскільки для їх створення була використана й бібліотека корабля, де було багато детективів і книжок з історії мови), окрім цього, ненавидять людей, які гноблять роботів і використовують їх зі своєю метою.

Надалі С. Лем із блискучою іронією, а інколи й філософським смутком продовжує розмірковувати про соціально-етичну природу штучного інтелекту й можливі перспективи його розвитку. Звичайно, письменника не може цікавити робот сам по собі. Штучне створіння, як і космос, є віддзеркаленням, проекцією свого творця, тобто людини. Якщо Бог створив людину за образом і подобою Своєю, людина відповідно створила штучну розумну істоту, то що нас очікує, коли ця істота стане творити щось принципово нове за своєю подобою, на свій погляд і смак?

Достатньо згадати оповідання «Машина Трурля», у якому механічний великий винахідник, який мав диплом Перпетуальної Омніпотенції, створив багатоповерхову обчислювальну машину. Та, на жаль, машина виявилася на рідкість дурною i впертою, уразливою та злопам'ятною, стверджувала, що двічі по два - сім, і за нешанобливе ставлення творця до неї вирішила його знищити.

Або інша блискуча новела «Як уцілів Всесвіт», у якій розповідається, як Трурль 
створив одного разу машину, що вміла робити все на букву «Н». Усе закінчилося тим, що механічна істота ледь не знищила увесь Всесвіт, оскільки їй дали завдання створити «Ніщо», тобто абсолютну порожнечу, яка теж починалася на букву «Н». Машина не зробила цього тільки тому, що добре усвідомлювала: у цьому фіналі вона перестала б існувати сама, як і все довкола.

Показово, що механічні істоти, а саме конструкторів Трурля та його друга Клапауція, письменник наділяє суто людськими властивостями - як позитивними, так і негативними: марнославством, недалекоглядністю, нетерпимістю, пихатістю й т. ін. Для письменника штучні створіння, як і космос, - це свого роду дзеркало, у якому людина впізнає себе збоку й усвідомлює як унікальне явище Всесвіту. Адже в навколишній світ людина має нести свої найбільші надбання: чуйність людської душі, жагу до пізнання й творчості, накопичену мудрість багатьох поколінь тощо.

Строго кажучи, ця думка стала провідною в оповіданні С. Лема «Дізнання», за яким було створено спільну радянсько-польську картину «Дізнання пілота Піркса» (1979, реж. М. Пестрак).

Якась приватна фірма розпочинає випуск людиноподібних роботів (кіборгів). На перший погляд, за мету поставлено досить гуманні цілі - замінити людину на найважчих i найнебезпечніших ділянках роботи. Але, керуючись насамперед економічними факторами, представники фірми не переймаються морально-етичними й соціальними наслідками наукового винаходу. Організація «Космікл-навігейшен» згодна придбати партію роботів, проте, побоюючись бойкоту з боку громадськості, вирішує провести експеримент, надавши йому широкого розголосу в пресі.

Для виконання завдання до Сатурна вирушає космічний корабель «Голіаф», на борту якого зведені разом люди й роботи, або, як їх називають, «нелінійники». Командирові корабля навігатору Пірксу належить з'ясувати, чи зможе робот замінити людину в космічному польоті, стати повноцінним членом екіпажу.

Щоб надати конфліктові філософської значущості й переконливо розкрити ідею в екранних образах, потрібно було створити яскраві образи героїв, у тому числі й роботів. Нелінійників належало наділити певними рисами різних характерів, своєю «психологією» так, щоб вони мали б цілком природний вигляд 3 погляду людської логіки й водночас суттєво б відрізнялися. Опонентами Піркса у фільмі стають роботи - лікар-нейрохірург Том Новак i перший пілот Джон Калдер. Експеримент ускладнюється тим, що нелінійники сконструйовані таким чином, що зовні нічим не відрізняються від людей: так само їдять, п’ють, розрізняють запахи, мають смакові рецептори й т. ін. Тому Пірксові випадає найскладніше - пізнати логіку їхнього мислення, зрозуміти мотиви їхніх учинків, відшукати їхні переваги, а також слабкі місця й вади. Завдання ускладнюється тим, що всі роботи мають як спільні характеристики, так і особисті відмінності.

Том Новак стає на бік Піркса, намагаючись усіляко сприяти тому, щоб експеримент отримав незадовільну оцінку й випуск нелінійників був зупинений. Він цілком відверто заявляє, що ним керує звичайний егоїзм і марнославство. Доки роботів мало, розмірковує Новак, у нього більше шансів проявити себе й «багато досягнути» серед людей, які значно програють порівняно 3 його можливостями. 
Адже, як тільки роботи перетворяться на серійну продукцію, його можливості різко скоротяться. А щодо етики, то, за його словами, у нього є свого роду «протез етики», він просто знає, як треба поводитися в конкретній ситуації.

Та якщо Новак займає вичікувальну позицію, то Джон Калдер налаштований більш рішуче. Він вирішує знищити людей і самостійно виконати завдання, доручене екіпажеві корабля. Проте Калдер не тільки відстоює свою особисту унікальність, він воліє, щоб людство вочевидь переконалося у вищості нелінійників, він навіть зазіхає на роль «володаря світу», який перебудує людство за своїми вподобаннями. «Ваш світ для мене безмежно порожній, - каже він, - ваші ідеали кумедні, а ваша демократія - це тільки влада інтриганів. I тоді я зрозумів, що роль слуги людини не задовольняє мене, тому я вирішив взяти владу в свої руки, щоб людство усвідомило, як воно помилилося, створивши подібну собі ляльку». В оповіданні Лема монолог Калдера видається ще агресивнішим: «Розділити вашу історію на два шматки - до мене і починаючи 3 мене, - змінити іiі абсолютно, розірвати на дві окремі частини, щоб ви зрозуміли та запам'ятали, що самі ж накоїли, коли створили мене, на що зазіхнули, замисливши зробити покірну людську ляльку...» [6, с. 397].

Та щоб характери розкрилися, потрібна конфліктна ситуація. Вона виникає несподівано й розвивається стрімко. Її розв'язкою стає аварія на кораблі, точно обчислена та спланована Калдером. Але, обчислюючи всі варіанти аварійної ситуації та ii наслідків, робот так само точно намагається обчислити поведінку людини в критичній ситуації. Оскільки всі можливі варіанти уникнення катастрофи повинні звестися до єдиного розв'язку, Калдер програмує накази Піркса, які й мають привести людей до загибелі. У критичній ситуації, коли катастрофа корабля стає невідворотною, Піркс раптом замовкає, перестає віддавати накази й тим самим порушує запрограмовану роботом логіку подій. У своїх розрахунках Калдер не спромігся врахувати тільки одного - здатності людини сумніватися. «Відверто кажучи, - скаже Піркс, - я не знав, що робити. Кожний мій наказ вів до катастрофи. I це моє мовчання Калдер сприйняв за хитрість! А мою неспроможність у цій ситуаціїза прозорливість, і тоді він почав діяти як людина і програв нам, людям».

В оповіданні Лема ця думка звучить дещо інакше: ситуація, створена аварією, нагадала Пірксові гру крапленими картами й він відмовився брати в ній участь. Письменник наголошує, що гідністю людини є не тільки їі здатність сумніватися, але насамперед іiі моральність, те, що називається порядністю й шляхетністю: «Зрештою, нас урятувала, а його згубила моя нерішучість, моя млява «порядність» - та людська «порядність», яку він так безмежно зневажав» [6, с. 412].

Цього разу людина перемогла. Проте фінал фільму залишається відкритим, адже штучні створіння вже живуть і працюють поміж людей, отже, цілком можливо, що головний бій іще попереду.

А от у картині американського режисера Р. Скотта «Той, що біжить по лезу бритви» (1982), знятої за мотивами частини книги Ф. Діка «Чи сняться андроїдам електровівці?», жодні компроміси між людиною та кіборгом неможливі. Тут боротьба точиться не на життя, а на смерть, питання лише в тому, хто кого здолає першим.

Сюжет стрічки досить простий і прямолінійний. На Землю потрапляють кілька 
втікачів-реплікантів, яких має виявити й знищити такий собі Рік Декард, назва професії якого перекладається 3 англійської як «живодер», «забійник» (blade runner). Різниці між людьми й реплікантами майже немає, їх видають тільки очі, що спалахують дивним світінням. Звичайно, героєві вдається впоратися 3 усіма небажаними гостями. Щоправда, якоїсь миті очі Декарта теж засвічуються червоними вогниками, від чого наростає інтрига: ким же він є насправді?

Надалі режисер розвиває цю інтригу, посилюючи сумніви щодо Декарта. 1993 р. Р. Скотт зняв так звану режисерську версію цього фільму з дещо іншим підтекстом, який указував, що Декарт усе ж таки був реплікантом. У 2000-2001 рр. Р. Скотт змонтував іще один варіант картини, який так i не вийшов на екран i в якому головний герой усе ж таки постає як штучна істота.

Цікаво, що після виходу першої версії кінострічки вона здобула глядацьку симпатію, проте у фахівців зазнала досить скептичних відгуків. Проте 1992 р. кілька відомих критиків змінили своє ставлення до картини. А в 2004 р., згідно 3 опитуванням британської газети «The Guardian», 60 учених назвали цей фільм «найкращим фантастичним фільмом усіх часів», при цьому він випередив «2001: Космічну одіссею» С. Кубрика.

Це наводить на думку, що акценти в осмисленні проблем робототехнічної теми суттєво змістилися. Вона дедалі більше почала зрощуватися 3 темою апокаліпсису. Кіборги стали не просто супротивниками людини, а запеклими ворогами всього людства, погрожуючи знищити цивілізацію своїх творців, про що, зокрема, красномовно розповідав фільм Дж. Кемерона «Термінатор» (1984) і наступні стрічки - «Термінатор 2: Судний день» (1991) і «Термінатор 3: Повстання машин» (2003, реж. Д. Мастоу). Адже, нарощуючи технічний потенціал, сучасна цивілізація чимдалі більше потрапляє в залежність від машин, штучного інтелекту. Людина перестає самостійно мислити, творити й кінець кінцем може втратити свободу вибору й дії.

По-друге, нового наповнення набуло питання: яким буде новий «чудовий» світ, котрий почне створювати штучний інтелект, котрий керуватиме світом людини? I яке місце в ньому відведено людині?

Саме цій проблемі присвячений культовий фільм Енді та Ларрі Войчовських «Матриця» (1999). Новий «чудовий» світ, який створив супермозок, де всі й усе існують у ноуменальному вимірі, де машини живляться від людей, а останні не усвідомлюють, що давно стали біороботами, підвладними штучному розумові й залежними від його волі.

Отож, що буде, якщо машина захоче «вдосконалити» людський світ на свій розсуд? Можливо, вона схоче зробити людей щасливими й безтурботними? Можливо, ій не сподобаються людські «вади» - нерішучість, здатність до сумнівів, схильність до рефлексії, співчуття й т. п. Але без цих «вад» людина вже не буде людиною. Залишиться світ, стерильний від почуттів та емоцій, де всі всім і завжди задоволені, постійно посміхаються, залишаючись байдужими, навіть коли зустрічаються зі смертю... Що може бути жахливішим?

I, нарешті, сьогодні постало, можливо, найболючіше питання про ймовірну кібергізацію самої людини, межі та критерії ii антропної унікальності, отже - 
перспективу розвитку сучасної цивілізації.

У цьому аспекті варто згадати американську кінострічку «Я, робот» (2004) режисера А.Пройаса, створену за мотивами циклу творів А. Азімова про позитронних роботів. Дія відбувається 2035 р., коли роботи стали звичною й невід'ємною частиною існування людства. Проте, як з'ясовується, один з роботів на ім'я Санні був звільнений від зв'язку ВІКІ (Віртуальний Інтерактивний Кінетичний Інтелект), отже, необхідності виконувати «три закони робототехніки», що зробило його етично рівним людині. У поліцейського детектива Спунера, який розслідує справу загибелі доктора Леннінга, провідного конструктора корпорації U.S. Robotics, свої порахунки 3 роботами. Якось машина Спунера й машина, у якій був дантист Ллойд із одинадцятирічною донькою Сарою, потрапили в аварію. Усім трьом загрожувала загибель, якби поруч не опинився один із роботів, який, попри прохання Спунера врятувати Сару, урятував його, мотивуючи тим, що в нього було більше шансів вижити. Унаслідок цієї ДТП Спунер отримав високотехнологічний кіберпротез лівої руки, отже, він не $є$ цілком людиною. Урешті-решт, «не зовсім робот» $\mathrm{i}$ «не зовсім людина» знаходять спільну мову, щоб упоратися 3 ВІКІ, яка спровокувала повстання машин. Фільм закінчується оптимістичним, хоча й сумнівним фіналом: позбавлені керівництва суперінтелекту, роботи визнають своїм лідером Санні, який свободою волі зрівнявся з людиною.

Коли фільм А.Пройаса вийшов у прокат (хоча проект був запущений ще 1998 р.), фантастичні ідеї вже набували цілком реальних рис. Того ж 1998 р. з'явилася перша в історії людства людина-кіборг. Нею став англійський професор Кевін Уорвік, якому в плече вживили двосантиметровий силіконовий мікропроцесор. Капсула дає змогу підтримувати постійний зв'язок із комп'ютерним центром університету й передавати інформацію про місцезнаходження професора та стан його здоров'я. Надалі Уорвік мав задум 3'єднати мікропроцесор комп'ютера зі своєю нервовою системою, i тоді 6 він остаточно перетворився на кіборга. Щоправда, надалі інформація про цей зухвалий експеримент не простежується. До речі, того ж таки 1998 р. професори Р. Бекей та Ф. Кеннеді з університету Еморі (штат Джоржія, США) уживили паралізованим пацієнтам під шкіру голови пристрій, менший за сірникову головку, завдяки якому вони можуть умикати й вимикати світло, пересувати ліжко, кликати помічників і навіть без інтернету спілкуватися з усім світом.

Вищеозначені проблеми набувають дедалі похмурішого забарвлення. Отож, де пролягає межа між залежністю й «волевиявленням» штучного інтелекту? У яких моральнісних вимірах повинен існувати зв'язок «людина - машина»? I де кордони антропного буття людини, яка зрощується зі штучною технологією?

Сучасна робототехнічна проблематика виводить на низку актуальних питань філософії. Людство саме бажає кіберготизуватися. До цього його спонукає одвічна мрія про безсмертя. Біологічна субстанція скінченна, а як щодо штучної? Якщо й вона не безсмертна, то принаймні набагато довговічніша. Наприклад, доктор технічних наук А. Болонкін, професор Інституту технології Стівенса в американському штаті Нью-Джерсі (Хобокен), пропонує майбутнє безсмертя шляхом заміни біологічних молекул напівпроводниковими мікрочипами. Такими чипами вчений пропонує 
замінити клітини мозку, таким чином забезпечуючи безсмертя. Отже, не виключено, що в XXI ст. з'явиться нова цивілізація. Ї̈̈ представників Болонкін називає ЛЕК людьми, еквівалентними комп'ютеру. Індивідуальне «я» стане практично безсмертним, оскільки його можна буде багаторазово перезаписувати. Надалі з'являться «андроїди» (напівлюди-напівроботи) із тілом, облаштованим різного роду датчиками, які заміняють органи почуттів, пристроями для пересування й комунікаційними системами. Окрім того, андроїди зможуть переселятися 3 одного тіла в інше шляхом перезапису чипів, тобто перепрограмовуватимуть себе. А біологічний спосіб розмноження заміниться клонуванням шляхом того ж таки перезапису чипів.

Сьогодні вчені поділилися на два визначальних табори: гуманітаріїв-гуманістів і трансгуманістів. Останні, як зазначає український філософ В. Лук'янець, ратують за право усвідомлено змінювати свій геном, своє тіло, свою нервову систему, що веде до перетворення людей на футуроїдів. За всіма полеміками «зрозуміло лише одне: практика використання технологій третього тисячоліття - це гігантський і вкрай ризикований експеримент над нашою цивілізацією в усій iii видовій та загальнокосмічній унікальності» [7, с. 9].

Свого часу М. Бердяєв, розмірковуючи над унікальністю природи людини, поставив знак рівняння між «свободою» й «творчістю»: «Творчість $\epsilon$ nерехід небуття у буття через акт свободи» [1, с. 45]. Людина відрізняється від тваринного світу передусім здатністю до створення нових цінностей, творення нового світу й здатністю до героїчного перенесення страждань і випробувань долі. Проте, як зазначає філософ, «існують кордони людської творчості, людина не може творити живих істот, може лише їх народжувати. Вона не може створити навіть блохи. I $є$ в цьому глибокий смисл. Істота, створена людиною, не мала б живого образу, була б лише механізмом» $[1$, с. 275$]$.

Проте творчість творчістю, але... Можливо, живучи в едемському саду, людина теж нагадувала біологічного робота, створеного за образом і подобою Бога, аж доки не скуштувала від дерева добра та зла й усвідомила себе особистістю, істотою не тільки душевною, а й духовною. «І сказав Господь Бог: «Ось став чоловік, немов один 3 Нас, щоб знати добро і зло» (Бут. 4: 22). Слід наголосити - не один із Нас, а немов один із Нас. Це свідчить, що людина ніколи не зрівняється зі своїм творцем, вона залишиться лише «немов».

Та чому б штучному створінню людини однієї чудової миті не стати «немов людиною»? I отримати якщо не дух, то принаймні душу чи ії подобу? Адже сьогодні роботам під силу не тільки механічні операції. Ще у 60-х рр. минулого століття Ф. Лейбер написав фантастичну історію «Божевільний дім у 64 клітини», у якому йшлося про робота, який, охоплений марнославством і пихою, бажав отримати шахову корону, і лише випадкова поломка завадила цьому. Цікаво, що $1997 \mathrm{p}$. шаховий матч Г. Каспарова й комп’ютера «Deep Blue», на відміну від 1989 і 1996 pp. (коли вигравав Каспаров) закінчився переконливою перемогою машини. Партія відбулася всього за 19 ходів і тривала близько години, тоді як партії в шахістів екстра-класу тривають у середньому близько чотирьох годин. Після матчу «Deеp 
Blue» був розібраний.

Ось ще один факт із життя роботів: 1 травня 2009 р. у театрі швейцарського міста Лозанна відбулася прем'єра мюзиклу «Роботи» режисера К. Денісара, у якому поряд 3 акторами участь брали три високотехнологічних роботи. Цікаво, що день прийдешній нам готує?

Сьогодні неможливо заперечувати, що робототехнічна проблематика набуває нових аспектів. Необхідно зважати, що сучасне покоління роботів запрограмоване на самовідновлювання й самовдосконалення, можливо, i на самовідтворювання собі подібних. Робот поступово створює все більшу конкуренцію людині. Це економічна сфера, види праці, у яких робот все більше заміщує людину. Це інтелектуальна й біологічна площини, у яких робот може дати фори людському видові. Звідси актуалізується сфера соціального життя, у якій робот має посісти своє місце, так би мовити, свою «соціальну чарунку». I головне - це сфера моралі. I якщо в роботів, цілком можливо, відсутня моральність (рос. нравственность), то своє уявлення про мораль, тобто - систему поглядів і уявлень, норм і оцінок, що регулюють поведінку, вони, мабуть, сформують. I яких форм набуде коеволюція людини і машини, можна тільки здогадуватися.

Ще 1931 р., задовго до ери роботів, М. Бердяєв наполягав на етиці техніки. Він писав, що машина набуває загального значення й на все «покладає свою печатку, усе собі уподібнює». Ототожнюючи силу й могутність людини, вона антропологічно ослаблює людину. «Техніка на своїй вершині може спричинити знищення більшої частини людства і навіть космічну катастрофу» [1, с. 198]. Саме тому потрібно подолати нейтральне ставлення до техніки, підпорядкувати іiі моральнісній, духовній енергії людини. Та чи зможе людство вирішити проблеми зі штучним створінням, якщо не може дати собі ради, улагодити свої стосунки?

Очевидно одне: майбутне роботехніки - задача з багатьма невідомими, але іiі розв’язання залежить від самої людини.

«У роботів - свої казки», - писав С. Лем; додамо: у роботів своя правда, казки, міфи, можливо, і своя історія. Проте в людства є своя історія. Свого часу в добре всім відомому фільмі «Пригоди Електроніка (1980, реж. К. Бромберг), у якому доступно роз'яснювалося, що машині - машинне, а людині - людське, була вилучена пісня «Ти - людина», якою закінчувалася остання серія телесеріалу. Зокрема в пісні були такі слова: «Куда подует ветер - туда и облака, куда пастух погонит - туда бредут стада, где рельсы проложили - там ходят поїзда, по руслу протекает послушная река...» А в приспіві повторювалося: «Ты - человек, ты - сильный и смелый, своими руками судьбу свою делай» (пісню повернули лише за часів горбачовської перебудови).

\author{
Література: \\ 1. Бердяєв Н. О назначении человека. М., 1993. \\ 2. Вертов Д. Мы. Вариант манифеста // Статьи. Дневники. Замыслы. М., 1966. \\ 3. Замятин Е. И. Мы // Избранное. М., 1989. \\ 4. Кларк А. Космическая Одиссея 2001 года. М., 1970. \\ 5. Куликова И. С. Философия и искусство модернизма. М., 1980.
}


6. Лем С. Дознание // Навигатор Пиркс. Голос неба. М., 1971.

7. Лукьянец В. «Мы входим в царство «НАНО», - но радоваться рано» // ВВС. 2007. № 04 (237).

8. Умов Н. А. Роль человека в познаваемом мире // Русский космизм: Антология философской мысли / составл. С. Г. Семеновой, А. Г. Гачевой. М., 1993.

9. Чапек K. R.U.R. // Сочинения : в 5 т. T. 3. М., 1958.

10. Ямпольский М. Б. Эксперименты Кульшова и новая антропология актера // Ноосфера и художественное творчество. М., 1991.

\section{Maryna Braterska-Dron}

\section{«AT WORK - YOUR CART» \\ (ROBOTIC ISSUES IN THE SOCIO-CULTURAL SPACE XX - EARLY XXI CENTURIES)}

Robotic problems are one of the most relevant in contemporary socio-cultural space. Mechanical man appeared in the cultural traditions of our civilization repeatedly. Its invariance is found even in the Upanishads, Kabbalah, the myths of Ancient Greece.

However, the theme of an artificial man in his modern work-engineering interpretation made the first step in the world from the easy hand of Karel Chapek, in his play «R.U.R.» (1920). It is the Czech writer introducing the term «robot» (in English translation). In essence, Karel Chapek in the early twentieth century. has defined the main philosophical aspects of modern robotics.

In this aspect, one should also mention the film by F. Lang «Metropolis» (1926), which dumped the work of technical topics to the general public.

The scientific and technological revolution that began after the Second World War expanded the imaginary possibilities of traditional science, determined the new technical perspectives of modern civilization, and at the same time meant the so-called related or negative trends of its development.

In 1941, A. Azimov in the story «The Liar!» postulates the main laws-tables of work equipment, starting a series of short stories called «I'm a robot». At the same time there is the term «work engineering».

In the 1960s, collections of Stories by S. Lemah «Sum of Technologies», «Fairy Tales of Robots», «Kyberiada» were published. In these works the main character becomes a robot. Like an English writer, S. Lem is trying to reproduce, so to speak, a formula not only purely human, but also artificial intelligence.

At the end of the 1950s, US engineers M. E. Klynse and N. S. Clin were working on the problem of human adaptation to the conditions of space and other planets. In the study, they concluded that the best way to solve this problem could be to combine man and work. Thus came the term «cyborg». From then on the robotic topic will be directly related to the space.

On this wave appeared a feature film by S. Kubrick «2001: Space Odyssey» (1968), filmed in the scenario of the science fiction writer A. Clark, in which the confrontation 
between man and machine goes to survival.

Even more gloomy coloring, the work-related problem is acquired in the film by R. Scott «Running on the razor blade» (1982). Apocalyptic motifs are more and more popular. Cyborgs become not just opponents of man, but fierce enemies of all mankind, threatening to destroy the civilization of their creators, about which, in particular, eloquently told the film D. Cameron «Terminator» (1984), etc.

And finally, today, perhaps the most painful question was the probable cyberhization of the person himself, as evidenced by the onset of transhumanism. So where are the boundaries of the anthropic existence of man, which is merged with artificial technology, and therefore - what is the prospect of the development of modern civilization?

Today it is impossible to deny that the working-engineering perspective acquires new aspects. The robot gradually creates more and more competition to a person. This is the economic sphere, the types of labor in which the robot is increasingly replacing a person. This is the intellectual and biological plane in which the robot can give the forefront a human species. From here, the sphere of social life, in which the robot should occupy its place, so to speak its «social cell», is actualized. And the main thing is the sphere of morality. And if robots are quite likely to lack understanding of human morality, then they will probably shape their ideas about the system of views and ideas, norms and evaluations that govern behavior. And what forms the co-evolution of man and machines can be guessed.

Братерська-Дронь Марина Тарасівна - доктор філософських наук, професор, завідувач кафедри кінознавства Київського національного університету театру, кіно і телебачення імені І. К. Карпенка-Карого (м. Київ).

Надійшла до редакції 07.06.2018. Розглянута на редколегії 25.06.2018.

\section{Рецензенти:}

Доктор філософських наук, професор, декан Національного аерокосмічного університету ім. М.С. Жуковського «ХАІ» Копилов В.О.

Кандидат філософських наук, доцент, доцент кафедри філософії Національного аерокосмічного університету ім. М.С. Жуковського «XАI» Широка С.I. 